\title{
Upaya Meningkatkan Kompetensi Guru Melalui Supervisi Akademik Di SMK Negeri 2 Paguyaman Tahun Pelajaran 2020/2021
}

\author{
Muchlis Harun \\ Kepala SMK Negeri 2 Paguyaman \\ muchlis@gmail.com
}

Received: 04 March 2021; Revised: 26 April 2021; Accepted: 28 July 2021

DOI: http://dx.doi.org/10.37905/aksara.7.3.1237-1244.2021

\begin{abstract}
Abstrak
Latar belakang dilakukannya Penelitian Tindakan Sekolah (PTS) ini yaitu rendahnya kompetensi pedagogik Guru Mata Pelajaran dalam proses pembelajaran di kelas. Solusinya yaitu dengan mengefektifkan pelaksanaan supervisi akademik. Permasalahannya apakah pelaksanaan supervisi akademik dapat meningkatkan kompetensi pedagogik guru dalam proses pembelajaran di kelas semester satu tahun 2020/2021 di SMK Negeri 2 Paguyaman. Tujuan penelitian ini adalah untuk mengetahui efektifitas pelaksanaan supervisi akademik dalam upaya meningkatkan kompetensi pedagogik Guru Mata Pelajaran dalam pembelajaran di kelas, yang manfaatnya bagi kepala sekolah adalah untuk mengetahui peningkatan kompetensi guru dalam proses pembelajaran.Penelitian ini dilaksanakan selama dua siklus, masing-masing siklus kegiatannya ada empat tahapan yaitu perencanaan, pelaksanaan, observasi, dan refleksi. Indikator keberhasilan dalam penelitian ini adalah; 1) hasil observasi kepala Sekolah maupun observasi guru selama proses pendampingan telah memperoleh skor rata-rata > $4,0,2)$ hasil akhir $>85 \%$ dari jumlah peserta pendampingan memperoleh nilai rata-rata > 70,00 (kategori baik). Hasil penelitian pada siklus I observasi Kepala Sekolah rata-rata $(3,40)$, observasi guru rata-rata $(3,17)$ dan hasil supervisi akademik Guru Mata Pelajaran rata-rata nilai $(68,56)$. Pada siklus II observasi kepala Sekolah rata-rata $(4,60)$ dengan persentase ketercapaian $(100 \%)$, observasi guru rata-rata $(4,50)$ dengan prosentase ketercapaian $(100 \%)$ dan hasil supervisi akademik rata-rata nilai $(83,67)$ dengan persentase ketercapaian (100\%). Indikator keberhasilan telah tercapai, penelitian di nyatakan berhasil dan dihentikan pada siklus II.Kesimpulan; Hasil penelitian pada siklus ke 2 menunjukkan peningkatan kompetensi Guru dalam proses pembelajaran di kelas senyatanya. Disarankan agar Kepala Sekolah lainnya melakukan penelitian sejenis dalam upaya peningkatan kompetensi guru, dan kepada Guru Mata Pelajaran sejenis agar melakukan proses pembelajaran sesuai dengan skenario yang telah direncanakan dengan baik, tanggung jawab, bersunggung-sungguh demi peningkatan prestasi belajar peserta didik sesuai dengan bidang studi/mata pelajaran yang menjadi tanggung jawabnya.
\end{abstract}

Kata kunci : Supervisi akademis, kompetensi Guru 


\section{PENDAHULUAN}

Upaya memperbaiki dan meningkatkan mutu pendidikan seakan tidak pemah berhenti. Banyak agenda reformasi yang telah, sedang, dan akan dilaksanakan. Reformasi pendidikan adalah restrukturisasi pendidikan, yakni memperbaiki pola hubungan sekolah dengan lingkungannya dan dengan pemerintah, pola pengembangan perencanaan, serta pola pengembangan manajerialnya, pemberdayaan guru dan restrukturisasi model model pembelajaran.

Reformasi pendidikan tidak cukup hanya dengan perubahan dalam sektor kurikulum, baik struktur maupun prosedur penulisannya. Pembaharuan kurikulum akan lebih bermakna bila diikuti oleh perubahan praktik pembelajaran di dalam maupun di luar kelas. Keberhasilan implementasi kurikulum sangat dipengaruhi oleh kemampuan guru yang akan menerapkan dan mengaktualisasikan kurikulum tersebut. Tidak jarang kegagalan implementasi kurikulum disebabkan oleh kurangnya pengetahuan, keterampilan dan kemampuan guru dalam memahami tugas tugas yang harus dilaksanakannya. Hal itu berarti bahwa guru sebagai pelaksana kegiatan pembelajaran menjadi kunci atas keterlaksanaan kurikulum di sekolah.

Pembelajaran dalam tataran idealnya harus direncanakan, dilaksanakan, dan dinilai oleh seorang guru serta diawasi oleh kepala sekolah. Namun, dalam praktiknya di lapangan hal ini yang tidak begitu diperhatikan oleh guru yang harus memiliki kompetensi pedagogik dan kepala sekolah yang harus memiliki kompetensi supervisor.

Dari hasil wawancara dengan kepala sekolah dapat disimpulkan bahwa kegagalan guru untuk membuat peserta didik itu belajar disebabkan karena faktor guru itu sendiri dan pengawasan kepala sekolah terhadap kinerja dari seorang guru yang bersifat instruksi bukan bersifat bimbingan atau bantuan. Sedangkan dari keterangan guru dapat disimpulkan bahwa, guru bingung ketika harus merumuskan RPP karena mata pelajaran yang diajar berbeda dengan latar belakang pendidikannya dan guru biasanya tinggal mengambil atau copy-paste dari MGMP.

Kondisi nyata yang terjadi di SMK Negeri 2 Paguyaman terhadap 6 (enam) guru mata pelajaran sebelum diadakan tindakan dalam upaya merubah mindset guru dari pola belajar guru aktif (guru sentris) ke pola belajar peserta didik aktif dapat dilihat pada data sebagai berikut: 1) ada yang Mengajar dengan mengedepankan pada belajar peserta didik aktif, 2) ada yang Mengajar dengan memperbanyak tugas-tugas, 3) ada yang Mengajar dengan ceramah (guru sentris), dan 4) ada yang Mengajar dengan memberikan catatan dan tugas.

Faktor Penyebab kondisi pembelajaran di kelas yang masih belum sesuai dengan Permen No. 41 Tahun 2007 tentang standar proses ini antara lain: 1) pembiasaan guru yang sudah membudaya, 2) kompetensi guru dalam proses pembelajaran di kelas senyatanya masih rendah, 3) guru kurang mempersiapkan perangkat pembelajaran sebelum masuk di kelas, 4) guru belum mampu merubah mindset cara mengajar kearah pembelajaran yang berbasis peserta didik aktif, dan 5) alasan-alasan lain yang bersifat konvensional seperti guru yang berpendapat yang penting mengajar dengan metode apa saja yang tidak terlalu ruwet dan materi pembelajaran selesai walaupun belum tuntas.

Solusi yang bisa dilakukan oleh kepala sekolah selaku peneliti sebenarnya banyak antara lain: 1) mengoptimalkan KKG bagi guru mata pelajaran, 2) mengadakan workshop terkait dengan penyusunan RPP yang baik dan benar dan tata cara mengajar yang mengarah kepada kegiatan peserta didik aktif, 3) mengadakan mikro teaching dan 
riil teaching dalam proses pembelajaran yang mengarah kepada kegiatan eksplorasi, elaborasi, dan komfirmasi, dan 4) mengoptimalkan supervisi dalam proses pembelajaran bagi guru mata pelajaran yang dititik beratkan pada tata cara mengajar yang baik dan benar di kelas senyatanya. Dengan mengoptimalkan pelaksanaan supervisi akademik yang terfokus pada kegiatan proses pembelajaran diharapkan mampu meningkatkan kompetensi guru mata pelajaran di SMK Negeri 2 Paguyaman dalam mengelola kegiatan pembelajaran kearah peserta didik aktif.

Dari beberapa solusi yang bisadilakukan oleh peneliti, alternatif yang paling strategis dan bisa merangkum dari semua solusi adalah dengan mengoptimalkan pelaksanaan supervisi akademik yang terfokus pada pelaksanaan proses pembelajaran di kelas senyatanya. Untuk melaksanakan supervisi akademik perlu dengan kegiatan yang bermanfaat bagi peneliti maupun bagi guru SMK Negeri 2 Paguyaman. Kegiatan dimaksud adalah dengan melakukan Penelitian Tindakan Sekolah (PTS) dengan judul "Upaya Meningkatkan Kompetensi Guru mata pelajaran SMK Negeri 2 Paguyaman Dalam Proses Pembelajaran Melalui Supervisi Akademik Semester Dua Tahun Pelajaran 2020/2021".Tujuan Penelitian adalahUntuk mengetahui efektifitas pelaksanaan supervisi akademik dalam proses pembelajaran di kelas senyatanya, upaya meningkatkan kompetensi guru mata pelajaran semester dua tahun 2020/2021 di SMK Negeri 2 Paguyaman

\section{METODE PENELITIAN}

Jenis penelitian yang digunakan adalah penelitian yang menggunakan desain Penelitian Tindakan Sekolah (PTS) dengan pendekatan kualitatif. Sugiyono (2009:10) mengemukakan bahwa penelitian kualitatif memandang objek sebagai sesuatu yang dinamis, hasil konstruksi pemikiran, dan interpretasi terhadap gejala yang diamati, serta utuh (holistik) karena setiap aspek dari objek itu mempunyai satu kesatuan yang tidak dapat dipisahkan, jadi realitas itu merupakan konstruksi atau interpretasi dari pemahaman terhadap semua data yang tampak di lapangan.

Penelitian ini merupakan suatu rangkaian langkah untuk mengatasi permasalahan yang timbul dalam ruang lingkup sekolah. Mulyasa (2009:9) mengemukakan bahwa penelitian tindakan sekolah (PTS) merupakan upaya untuk meningkatkan kinerja sistem pendidikan dan mengembangkan manajemen sekolah agar menjadi lebih produktif, efektif, dan efisien. PTS dapat diartikan sebagai sebuah upaya untuk memperbaiki kondisi dan memecahkan berbagai persoalan pendidikan yang dihadapi di sekolah. Pengertian tersebut menunjuk pada dua kata yang satu diantaranya harus ada dalam kegiatan penelitian tindakan sekolah, yaitu pemecahan masalah (problem solving) dan peningkatan (improving) kinerja sistem pendidikan serta manajemen sekolah, yang secara keseluruhan akan berdampak pada peningkatan mutu. Lebih lanjut Aqib (2009:3) juga mengungkapkan bahwa hakikat dari kegiatan PTS adalah seorang kepala sekolah atau pengawas yang memperbaiki kualitas penyelenggaraan pendidikan.

Subjek penelitian dalam penelitian ini adalah guru produktif di SMK Negeri 2 Paguyaman, jumlah subjek penelitian ini 6 guru mata pelajaran. Penelitian ini dilaksanakan Sejak bulan januari 2021 hingga april 2021 sehingga dapat dikatakan waktu penelitian ini pada tahun pelajaran 2020/2021.

Penelitian ini difokuskan pada kompetensi awal guru dalam mengembangkan silabus dan menyusun RPP menurut Permendiknas No 41 Tahun 2007, penerapan 
supervisi akademik dalam meningkatkan kompetensi guru dalam menyusun RPP menurut Permendiknas No 41 Tahun 2007, dan peningkatan kompetensi guru dalam menyusun RPP menurut Permendiknas No 41 Tahun 2007. Dalam penelitian ini tidak melihat aspek lain selain standar proses yang membuat peningkatan kompetensi guru produktif dalam mengembangkan silabus dan menyusun RPP.

Instrumen penelitian merupakan alat bantu dalam mengumpulkan data. Dalam penelitian ini yang berorientasi pada proses membuat peneliti berfokus pada proses tindakan yang meliputi perilaku supervisor dan guru, respon dari guru mengenai supervisor dan tindakan yang diberikan, dan suasana proses tindakan sehingga penelitilah yang menjadi instrumen kunci dengan bantuan lembar observasi dan pedoman wawancara. Selain itu untuk menilai kompetensi guru dalam menyusun RPP supervisor memberikan penilaian berpedoman pada APKG (Acuan Penilaian Kompetensi Guru) kemudian supervisor memberikan umpan balik dengan berpedoman pada hasil penilaian menurut APKG dan berdasarkan komponen serta prinsip penyusunan RPP menurut Permendiknas No 41 Tahun 2007, umpan balik dari pengawas sekolah/supervisor ini berguna untuk mengetahui kekurangan dari RPP yang dibuat guru. Catatan lapangan dari dokumentasi (Hasil penilaian \& umpan balik pengawas sekolah/supervisor) dipakai untuk mendeskripsikan kondisi awal kompetensi guru dalam mengembangkan silabus dan menyusun RPP dan peningkatan kompetensi guru produktif dalam mengembangkan silabus dan menyusun RPP, sedangkan catatan lapangan dari observasi, wawancara, dan dokumentasi (foto) digunakan untuk mendeskripsikan penerapan tindakan yang dilakukan meliputi bagaimana perilaku supervisor, perilaku subjek penelitian, dan suasana yang terjadi saat itu terhadap pembelajaran.

Teknik analisis data yang digunakan dalam penelitian ini adalah naratif kualitatif yakni mendeskripsikan atau menggambarkan bagaimana kondisi awal kompetensi guru dalam menyusun RPP, pelaksanaan tindakan memberikan supervisi pada guru untuk menyusun RPP yang sesuai dengan Permendiknas No 41, dan peningkatan yang dialami guru dalam menyusun RPP. Miles \& Huberman (Dalam Sugiyono, 2009:246) mengemukakan bahwa aktivitas dalam analisis data kualitatif dilakukan secara interaktif dan berlangsung secara terus sampai tuntas, sehingga datanya sudah jenuh. Aktivitas dalam analisis data, yaitu reduksi data, penyajian data, dan penarikan kesimpulan.

Penelitian ini terbagi menjadi dua siklus yakni siklus I \& siklus II. Kegiatan siklus I ini berguna untuk mengetahui kompetensi awal guru dalam mengembangkan dan menyusun RPP menurut Permendiknas No 41 Tahun 2007. Dari hasil penilaian dan umpan balik yang telah diberikan supervisor dapat disimpulkan bahwa terdapat kesenjangan antara RPP yang dibuat guru dan RPP menurut Permendiknas No 41 Tahun 2007 terutama dalam perumusan langkah kegiatan inti yang belum menampilkan proses eksplorasi, elaborasi, serta konfirmasi dan instrumen penilaian yang belum lengkap. Siklus I terdiri perencanaan, pelaksanaan, observasi, dan refleksi. Dalam kegiatan perencanaan tindakan supervisor membuat kesepakatan waktu dan tempat bersama subjek penelitian untuk berdiskusi tentang mengembangkan silabus, RPP yang telah dibuatnya, menyiapkan rencana pelaksanaan pertemuan, menyiapkan materi yang akan disampaikan, menyiapkan lembar observasi kegiatan, dan menyiapkan pedoman wawancara. 


\section{HASIL PENELITIAN \\ SIKLUS I \\ Tahap Perencanaan}

Pada tahapan ini peneliti telah berhasil: 1) menyusun materi tentang supervisi akademik, 2) menetapkan skenario dan langkah-langkah pendampingan, 3) menyusun instrumen observasi Kepala sekolah observasi guru, dan instrumen kegiatan supervisiakademik, 4) menentukan jadwal kegiatan supervisi akademik yang terbagi menjadi 2 (dua) pertemuan, pertemuan I pelaksanaan pendampingan klasikal, Pertemuan ke 2 (pendampingan individual/supervisi akademik)

\section{Tahap Pelaksanaan}

Pada tahapan ini peneliti melakukan 2 (dua) kegiatan yaitu kegiatan pendampingan/pembimbingan secara klasikal, dan kegiatan kedua adalah pelaksanaan supervisi akademik di kelas senyatanya.

\section{Tahap Pengumpulan/Pengumpulan Data}

Hasil Observasi Kepala Sekolah memperoleh skor rata-rata sebesar 3,40, observasi guru memperoleh skor rata-rata sebesar 3,17, dan hasil supervisi akademik di kelas memperoleh nilai rata-rata sebesar 68,56.

\section{Tahap Refleksi}

Pada tahap ini peneliti melakukan beberapa kegiatan yang merupakan tahapan akhir dari pelaksanaan siklus I, yaitu kegiatan perencanaan, pelaksanaan, dan observasi. Adapun kegiatan secara rinci meliputi: 1) renungan atas data hasil observasi dan hasil pengamatan selama proses pembelajaran di kelas senyatanya, 2) pengolahan data hasil penelitian dan mencocokkan dengan indikator keberhasilan, 3) rencana perbaikan dan penyempurnaan, 4) memberikan penguatan atas hasil yang diperolehnya, dan 5) rencana tindak lanjut

\section{SIKLUS II}

\section{Tahap Perencanaan}

Pada tahapan ini peneliti kegiatannya masih mengacu pada siklus I yakni merencanakan: 1) penyusunan materi tentang supervisi akademik, 2) menetapkan skenario dan langkah-langkah pendampingan, 3) menyusun instrumen observasi Kepala sekolah dan observasi guru, 4) menentukan jadwal kegiatan supervisi akademik, 5) menyusun pedoman analisa data hasil observasi dan hasil supervisi akademik.

\section{Tahap Pelaksanaan}

Pada tahapan ini peneliti kegiatannya adalah masih sama dengan siklus I, bedanya pada siklus II ini pelaksanaannya lebih dioptimalkan karena kesalahankesalahan dan kekurangan pada siklus I sudah di deteksi dan sudah dicari jalan keluarnya. Tahap Pengamatan/Pengumpulan Data

Hasil Observasi Kepala Sekolah memperoleh skor rata-rata sebesar 4,60, observasi guru memperoleh skor rata-rata sebesar 4,50, dan hasil supervisi akademik di kelas memperoleh nilai rata-rata sebesar 83,67.

\section{Tahap Refleksi}

Pada tahapan ini peneliti melakukan kegiatan penyempurnaan terhadap kesalahan-kesalahan yang terjadi pada siklus I. Adapum untuk kegiatannya adalah: 1) renungan atas data hasil observasi Kepala sekolah dan guru serta hasil supervisi akademik 
di kelas, 2) pengolahan data hasil penelitian dan mencocokkan dengan indikator kinerja, 3) rencana perbaikan dan penyempurnaan, 4) memberikan penguatan atas hasil yang diperolehnya, dan 5) rencana tindak lanjut.

\section{PEMBAHASAN \\ SIKLUS I \\ Tahap Perencanaan}

Ada beberapa kendala yang dihadapi dalam tahapan ini, diantaranya dalam penyusunan materi tentang supervisi akademik, dalam persiapan skenario tindakan selama pendampingan klasikal, dalam penyusunan instrumen observasi Kepala sekolah dan instrumen observasi peserta pendampingan, dalam penentuan jadwal supervisi akademik bagi 6 (enam) guru mata pelajaran, menentukan penyusunan pedoman analisa data hasil observasi Kepala sekolah, observasi guru dalam proses pembelajaran di kelas dan hasil supervisi akademik dari ke 6 (enam) guru mata pelajaran, tetapi setelah berkonsultasi dan meminta petunjuk kepada pembimbing, kendala yang dihadapi pu dapat diatasi dan kegiatan perencanaan dapat berjalan dengan lancar.

\section{Tahap Pelaksanaan}

\section{Pertemuan I}

Dalam melaksanakan pendampingan klasikal tentang perlunya pendampingan dan penyampaian materi tentang supervisi akademik yang kegiatan nyatanya menjelaskan bagaimana cara mengajar yang baik dan benar sesuai dengan instrumen yang telah ditetapkan, serta pelaksanaan tanya jawab kepada peserta mengalami hambatan.

\section{Pertemuan II}

Pelaksanaan supervisi akademik dalam proses pembelajaran upaya meningkatkan kompetensi pedagogik bagi guru mata pelajaran di mulai sesuai dengan jadwal yang telah disepakati bersama.

\section{Tahap Pengamatan/Pengumpulan Data}

Pengamatan/observasi Kepala sekolah oleh pengawaspembimbing selaku observers pada kegiatan pendampingan klasikal (pertemuan I) berjalan lancar, artinya tidak ada kendala.Hasil skor ratarata yang diraih oleh Kepala sekolah/peneliti $(3,40)$ kategori cukup dari indikator keberhasilan yang diharapkan yaitu > 4,00 (kategori aktif). Sementara itu hasil observasi guru oleh peneliti selama proses pendampingan klasikal, dilihat dari aktifitas dari ke enam guru mata pelajaran memperoleh rata-rata $(3,17)$ kategori cukup dari indikator keberhasilan yang direncanakan yaitu > 4,00 (kategori aktif). Pada pertemuan kedua yakni pelaksanaan supervisi akademik yang terfokus pada pelaksanaan proses pembelajaran di kelas senyatanya.Perolehan nilai rata-rata hasil supervisi akademik dari 6 (enam) guru mata pelajaran diperoleh hasil $(68,56)$ dengan presentase ketuntasan 33,33\%, 3

\section{Tahap Refleksi}

Setelah semua perolehan data dianalisis dan di cocokkan dengan indikator keberhasilan, diperoleh data sebagai berikut:Hasil Observasi Kepala Sekolah $(3,40)$, Hasil Observasi Guru $(3,17)$, dan Hasil Supervisi Akademik $(68,56)$. 


\section{SIKLUS II}

\section{Tahap Perencanaan}

Pada tahapan ini peneliti telah memperbaiki semua kekurangan dan kesalahankesalahan yang dilakukan pada siklus I. Pada siklus II semua perencanaan tidak ada hambatan artinya berjalan sesuai dengan rencana yang telah ditetapkan. Kegiatankegiatan nyata yang dilakukan tidak ada hambatan adalah: 1) penyusunan materi pendampingan berkaitan dengan supervisi akademik, 2) penetapan/penyusunan skenario tindakan, 3) penyusunan instrumen observasi, 4) penentuan jadwal kegiatan, dan 5) penyusunan pedoman analisa data. Beberapa hal yang sangat berkesan pada tahapan ini antara lain; 1) peneliti bisa membuat guru mata pelajaran merasa lega dan merasakan akan manfaat supervisi akademik dalam proses pembelajaran, 2) pengawas pembimbing juga merasa puas dengan persiapan peneliti melalui kegiatan pada tahap perencanaan.

\section{Tahap Pelaksanaan Pertemuan I}

Peneliti melakukan pendampingan klasikal dengan mengoptimalkan tindakan nyata terutama kesalahan-kesalahan/kekurangan yang terjadi pada siklus I lebih dioptimalkan, sehingga dalam pelaksanaan pendampingan pada siklus II ini berjalan lancar tanpa hambatan yang berarti.

\section{Pertemuan II}

Pelaksanaan supervisi akademik di kelas senyatanya berjalan sesuai jadwal yang telah ditetapkan. Semua guru mengajar dikelas tepat waktu.

\section{Tahap Pengamatan/Pengumpulan Data}

Hasil pengamatan penampilan Kepala sekolah/peneliti yang dilakukan oleh observer, maupun hasil pengamatan guru selama proses pendampingan oleh kepalasekolah diperoleh data sebagai berikut: Hasil Observasi Kepala Sekolah $(4,60)$, Hasil Observasi Guru (4,50). Perolehan hasil supervisi akademik pada siklus II memperoleh skor rata-rata (81,22/kategori baik) dan dinyatakan $100 \%$ tuntas. Hasil ini merupakan dampak positif dari upaya mengoptimalkan tindakan pelaksanaan supervisi akademik dikelas senyatanya.

\section{Tahap Refleksi}

Hasil observasi Kepala sekolah, guru peserta pendampingan serta hasil supervisi akademik di kelas senyatanya telah melebihi indikator keberhasilan yang telah ditetapkan. Penelitian Tindakan Sekolah (PTS) dinyatakan telah berhasil dan dihentikan pada siklus II, dengan perolehan peningkatan sebagai berikut:Hasil Observasi Kepala Sekolah (4,60), Hasil Observasi Guru (4,50), dan Hasil Supervisi Akademik $(83,67)$. Peneliti memberikan reward/penghargaan kepada semua guru peserta pendampingan atas hasil yang diraih dan mampu memperoleh nilai diatas rata-rata indikator yang telah ditetapkan. Perbaikan dan penyempurnaan kegiatan tidak perlu dilakukan karena penelitian telah berhasil mencapai indikator yang telah ditetapkan. Penelitian Tindakan Sekolah (PTS) dinyatakan "BERHASIL" dan dihentikan pada siklus II.

\section{PENUTUP}

Upaya mengoptimalkan pelaksanaan supervisi akademik dalam proses pembelajaran bagi guru mata pelajaran SMK Negeri 2 Paguyamansemester dua tahun 2016/2017, upaya meningkatkan kompetensi guru dalam proses pembelajaran di kelas, dinyatakan berhasil karena dari perolehan data pada siklus II telah mampu melampaui 
indikator keberhasilan dan mengalami peningkatan dari siklus I ke siklus II yang sangat signifikan. Penelitian Tindakan Sekolah (PTS) dinyatakan "Berhasil" dan dihentikan pada siklus II.Paparan data hasil Penelitian Tindakan Sekolah (PTS).

Bagi Guru mata pelajaran diharapkan agar: 1) Merencanakan kegiatan pembelajaran dengan sebaikbaiknya dengan strategi pembelajaran yang mengarah ke peserta didik aktif, kreatif, inovatif, dan demokratif, 2) Melakukan proses pembelajaran sesuai dengan skenario yang telah direncanakan dengan baik, tanggung jawab, bersunggung-sungguh demi peningkatan prestasi belajar peserta didik sesuai dengan bidang studi/mata pelajaran yang menjadi tanggung jawabnya

\section{DAFTAR PUSTAKA}

Departemen Pendidikan dan Kebudayaan RI. 1982. Alat Penilaian Kemampuan Guru: Buku I. Jakarta: Proyek Pengembangan Pendidikan Guru.

- 1982. Panduan Umum Alat Penilaian Kemampuan Guru.Jakarta: Proyek Pengembangan Pendidikan Guru.

. Alat Penilaian Kemampuan Guru: Hubungan antar Pribadi.Buku III. Jakarta: Proyek Pengembangan Pendidikan Guru.

. Alat Penilaian Kemampuan Guru: Prosedur Mengajar. Buku II. Jakarta: Proyek Pengembangan Pendidikan Guru.

Suhardjono, A. Azis Hoesein, dkk (1995). Pedoman penyusunan KTI di Bidang Pendidikan dan Angka Kredit Pengembangan Profesi Guru. Digutentis, Jakarta : Diknas

Suhardjono. 2005. Laporan Penelitian Eksperimen dan Penelitian Tindakan Kelas sebagai KTI, makalah pada Pelatihan Peningkatan Mutu Guru di LPMP Makasar, Maret 2005

Suhardjono. 2009. Tanya jawab tentang PTK dan PTS, naskah buku.

Suharsimi, Arikunto. 2002. Penelitian Tindakan Kelas, Makalah pada Pendidikan dan Pelatihan (TOT) Pengembangan Profesi bagi Jabatan Fungsionla Guru, 11-20 Juli 2002 di Balai penataran Guru (BPG) Semarang.

Suharsimi, Suhardjono dan Supardi. 2006. Penelitian Tindakan Kelas. Jakarta : PT Bumi Aksara

Supardi. 2005. Penyusunan Usulan, dan Laporan Penelitian Penelitian Tindakan Kelas, Makalah disampaikan pada "Diklat Pengembangan Profesi Widyaiswara", Ditektorat Tenaga Pendidik dan Kependidikan Dirjen Pendidikan Dasar dan Menengah, Departemen Pendidikan Nasional 